\title{
Assessment and Mapping of Environmentally Sensitive Areas To Desertification Using Gis in An Area of The North Delta Region of Egypt
}

F.S. Moghanm* and A. B. Belal **

* Soil and Water Science Department-Faculty of Agricultural-Kafrelsheikh University, Kafr El-Sheikh 33511, Egypt

**Agricultural Applications, Soil and Marine Science Division, National Authority for Remote Sensing and Space Sciences, P.O. Box 1564, Alf Maskan, Cairo, Egypt.

$\mathbf{T}$ HIS STUDY aims to delineate areasin the northern Nile Delta of Egypt that are sensitive to desertification using integrated remote sensing and geographic information systems (GIS).

Desertification is one of the fundamental problems associated with land degradation in arid and semi-arid regions. Desertification results from several factors, including climate change, chemical and physical degradation and human activities.

Thematic indicators of soil, climate, vegetation, and management practices represent essential data and are required to approximately define theenvironmentally sensitive areas (ESAs). These layers are extracted and manipulated from topographic maps, geologic maps, land use intensity data, policy enforcement data, satellite imagescollected by the Enhanced Thematic Mapper Plus (ETM+) sensor in 2015, and data obtained during field surveys. The functions of the Spatial Analyst Toolbox in the ArcGIS 10.1 software package are used to collect the thematic layers and identify theESAs.

The resultsobtained in this study reveal that the sensitiveareas to desertification were located in the northern parts of the study area. These vulnerable areas are located around Lake Burullus and represent 19\% of the study area. Also, the results indicate thatthe central part of the study areaexhibitsfragile areas that are sensitivetodesertification and represent $24 \%$ of the total area. The southern parts of the study area are characterized by critical sensitivity and represent $57 \%$ of the total area. The impact factors that affectthe sensitivity to desertificationare soil salinity, waterlogging and management indicators in the study area.

Keywords: Remote sensing, GIS, Environment, Environmental sensitivity, Desertification.

\section{Introduction}

Desertification refersto indicators that reflect a potential risk of desertification. Regional indicators arebased on available data, including remote sensing images, topographic maps, climatological data, soil, and geological data (Nicholson et al., 1998, Gargi, 2015, Gyssels et al., 2016 and Lahlaoi et al., 2015).

Soil desertification is the end result of differentinteractions amongmany factors, including environmental change and human activities (Thomas, 1997, USDA, 2004). Many countries (more than 100)and approximately 15 percent of the world's population of six billion peopleare affected by desertification(Adger et al., 2000, Adger et al., 2001). However, desertification phenomena can be accurately monitored and evaluated through matching satellite images to survey data(Jabbar and Chen, 2006, Runnström, 2003, Yang et al., 2007, Zambon et al., 2017).

Areas that are sensitiveto desertification in Mediterranean countries display different sensitivities to desertification, depending on 
theconditions within each area. For instance, some territories display high sensitivity to low precipitation and extreme events because they contain vegetation that is weakly resistant to dry spells, low vegetation cover, gentle slopes, and highly erodible parent materials(Ferrara et al., 1999). The occurrence of desertification incorporates two components: human actions and natural ecosystems(World Meteorological Organization, 2005). The interactions between these two factors determine the severity of the degradation, and desertification assessments are based on climate conditions and the characteristics of vegetation and soil (Jabbar and Chen, 2006). Various studies monitored and assessed ESA by using MEDALUS model in the Mediterranean region with acceptable results (Saleh et al., 2018, Lahlaoi et al. 2017).

Remote sensing data and GIS have made enormous contributions in the field of assessing environmental sensitivityto desertification, and GIS has been shown to be a very useful toolin the preparation, manipulation, visualization and analysis of spatially referenced data (Westervelt, 2002, Saleh et al., 2018, Coscarelli et al., 2016).

This study aims to identify areas that are sensitive to desertification using a multi-factor approach that incorporates both large-scaleand localized information on the environmental processes acting in the northern part of Egypt into spatial analyses.

\section{Materials and Methods}

\section{Study Area}

The study area is located in the northern part of the Nile Delta in Egypt. This region extends from $30^{\circ} 35^{\prime}$ to $31^{\circ} 00^{\prime}$ east longitude and from $31^{\circ} 10^{\prime}$ to $31^{\circ} 28^{\prime}$ north latitude, and it covers an area of $720 \mathrm{~km}^{2}$; urban areas make up $6.25 \%$ ofthe total area (Fig.1). The climatic conditions withinthe study area are typically arid and semiarid; the annual rainfall occurs primarily during the winter season and reaches approximately $167 \mathrm{~mm} /$ year. The maximum rainfall values are recorded in December and January. The annual evaporation reaches its maximum in August at $7 \mathrm{~mm} /$ day. The minimum values are detected in December and January, when temperatures are low; on the other hand, the highest values are recorded between March and October. The air temperatures in December and August are 15.0 and $30.5^{\circ} \mathrm{C}$, respectively (Climatological Normal for Egypt, 2011).

Image processing and physiographic units:

Digital image processing of Enhanced ThematicSatellite Images $\left(\mathrm{ETM}^{+}\right)$covering the study areais performed using ENVI 5.1 software (ITT, 2014) to delineate the geomorphologic units. These satellite images were collected along path 177 and row 038 in 2015 . The image processing is carried out using the ENVI 5.1 software package and includes data calibration (Lillesand and Kiefer, 2007), data manipulation, atmospheric correction, rectification of the satellite images and enhancement of the ground resolution from 28.5 $\mathrm{m}$ to $14.25 \mathrm{~m}$ (Lillesand and Kiefer, 2007).

The digital elevation model (DEM) of the study area extracted from the topographic maps has a scale of 1:25000. The DEMwas combined with theLandsat $\mathrm{ETM}^{+}$images to recognize different landform types, and it is assist in detecting a range of propertiesthat can assist in mapping landforms and soil types. The
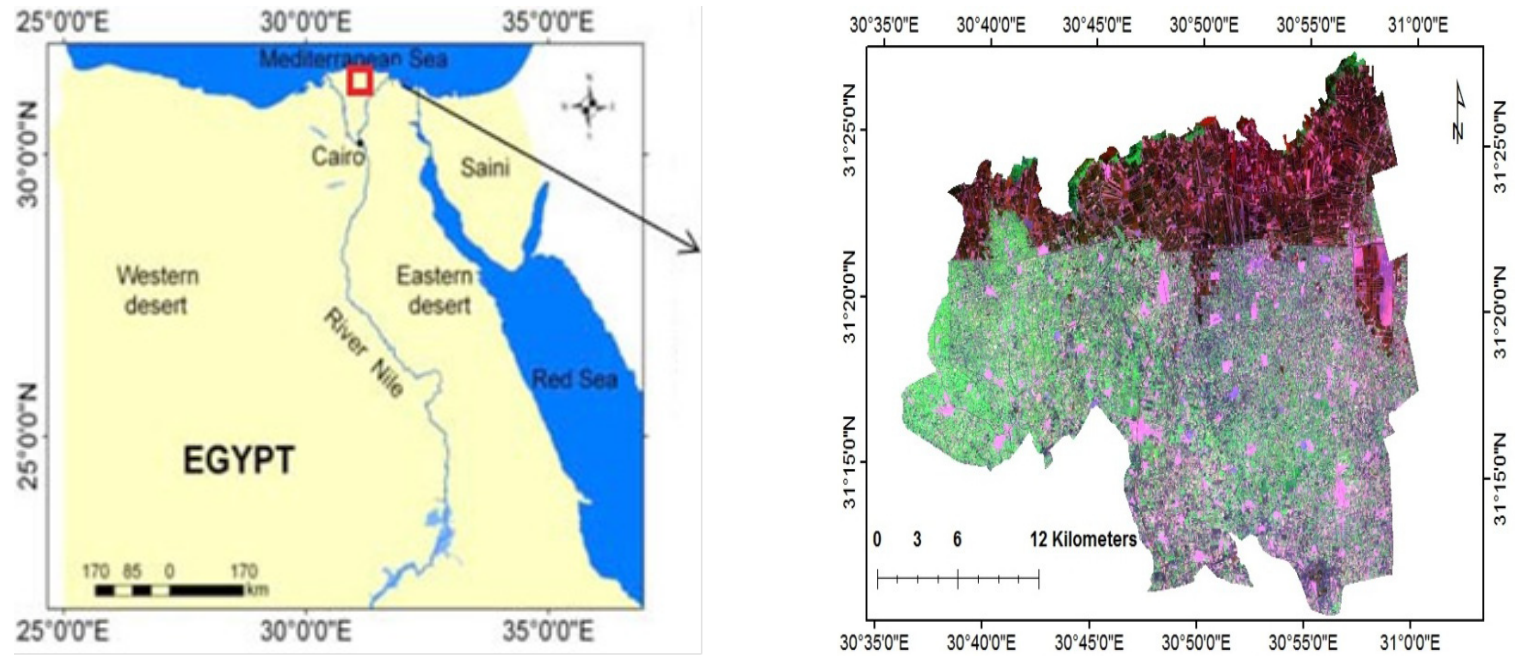

Fig. 1. Location of the study area shown on a map of Egypt and a Landsat ETM+image of the study area

Egypt. J. Soil Sci. 58, No.3 (2018) 
information extracted from a DEM (i.e., surface elevation, slope and slope direction) is used with the satellite images to increase their utility in physiographic soil mapping .The Landsat ETM ${ }^{+}$ images and the DEMs weremanaged in the ENVI 5.1 software package and ARCGIS Software to obtain the physiographic units and establish asoil database (Dobos et al., 2000).

\section{Field work and laboratory analysis:}

These profiles were carefully chosen based on the different physiographic landforms (Fig.2) that existed in the study area in 2015 . The soil profiles were examined and morphologically described in the field according to FAO (1990). Water samples from irrigation, drainage and water table sources were collected near the soil profile locations. The soil and water samples wereanalysedto determine their chemical and physical properties according to USDA (2004).

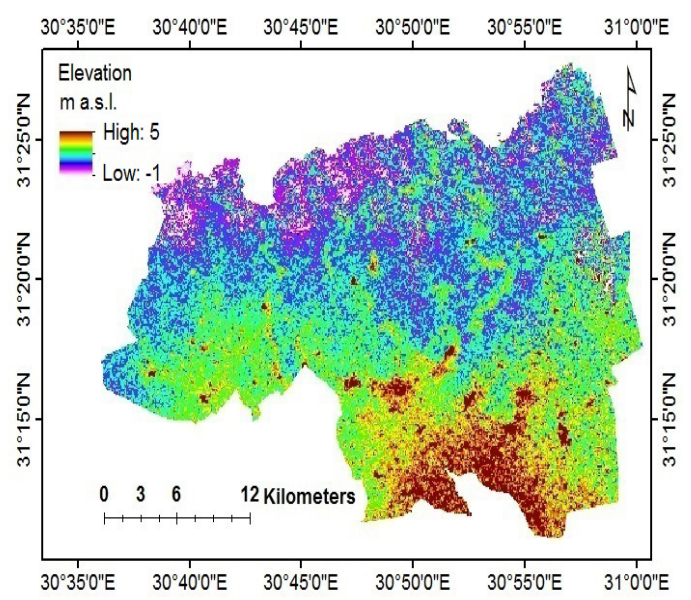

\section{Methods}

The Medalus (Mediterranean Desertification and Land Use) model is used to assess the environmentally sensitive areas (ESAs), and the relevant index is used to determine the state of desertification and the tendency to desertification in the northern Nile Delta of Egypt. The general methodology has beenfully describedby (Kosmas et al., 1999). The ESA is a combined index that uses four quality indices calculated from severalindividual parameters. The quality indices and their parameters are as follows. The soil quality index (SQI) is calculated based on the surface gradient and the texture, drainage conditions, parent material, and depth of the soil, as well asthe abundance of rock fragments within the soil. Theclimate quality index (CQI) is calculated based on the annual rainfall and aridity. Thevegetation quality index (VQI) is calculated based on the fire

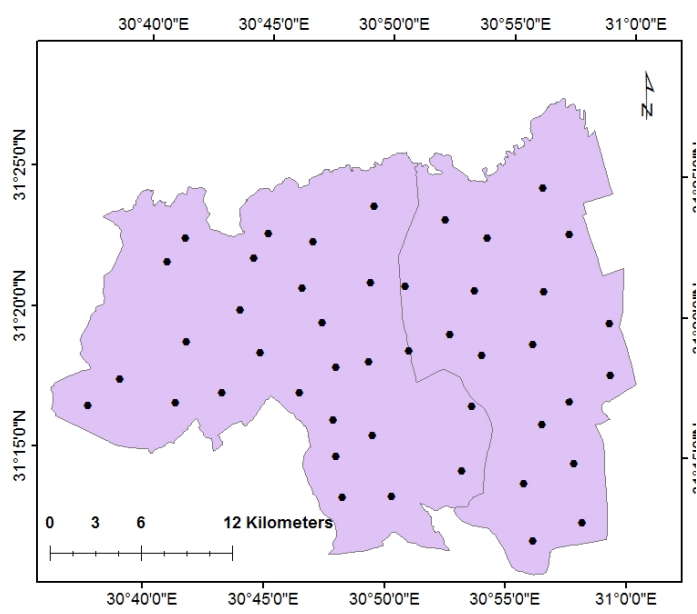

Fig. 2. Maps showing a digital elevation model (DEM) of the study area and the locations of the soil profiles

risk and the degree of erosion protection, cover and drought resistance. Finally, the management quality index (MQI) is calculated based on land use and management practices. The value of each parameter is separated into a number of classes, the thresholds of which have been determined empirically from extensive field work throughout the MEDALUS project (Kosmas et al., 2003). Many studies have shownthat the MEDALUS model evaluates the desertification rate accurately and provides acceptable results (Kosmas et al., 2003, Sepehr et al., 2007, Lavado et al., 2009).

The ESA index is calculated according to the flow chart shown in Fig.3. This flow chart shows the conceptual model followed incalculating all of the indices. The main input to this model is mosaicked $\mathrm{ETM}^{+}$satellite images, the geologic map of the study area, and climatic data. The ENVI 5.1 and ArcGIS software packagesare used to calculate these indices and create maps of ESAs.

\section{Results and Discussion}

\section{Physiographic map:}

The two physiographic landscapes that occur within the study arearepresentfluvio-lacustrine plains and flood plains. These landscapes consist of eightlandforms, specificallydecantation basins, dried lake beds, moderately terraces, moderately high river terraces, overflow basins, overflow mantles, seasonally submerged land and wet lands. These landforms cover 7.94, 9.85, 14.49, $14.80,22.24,9.16,2.15$ and $19.37 \%$ of the total area, respectively (Fig.4).

Egypt. J. Soil Sci. 58, No. 3 (2018) 


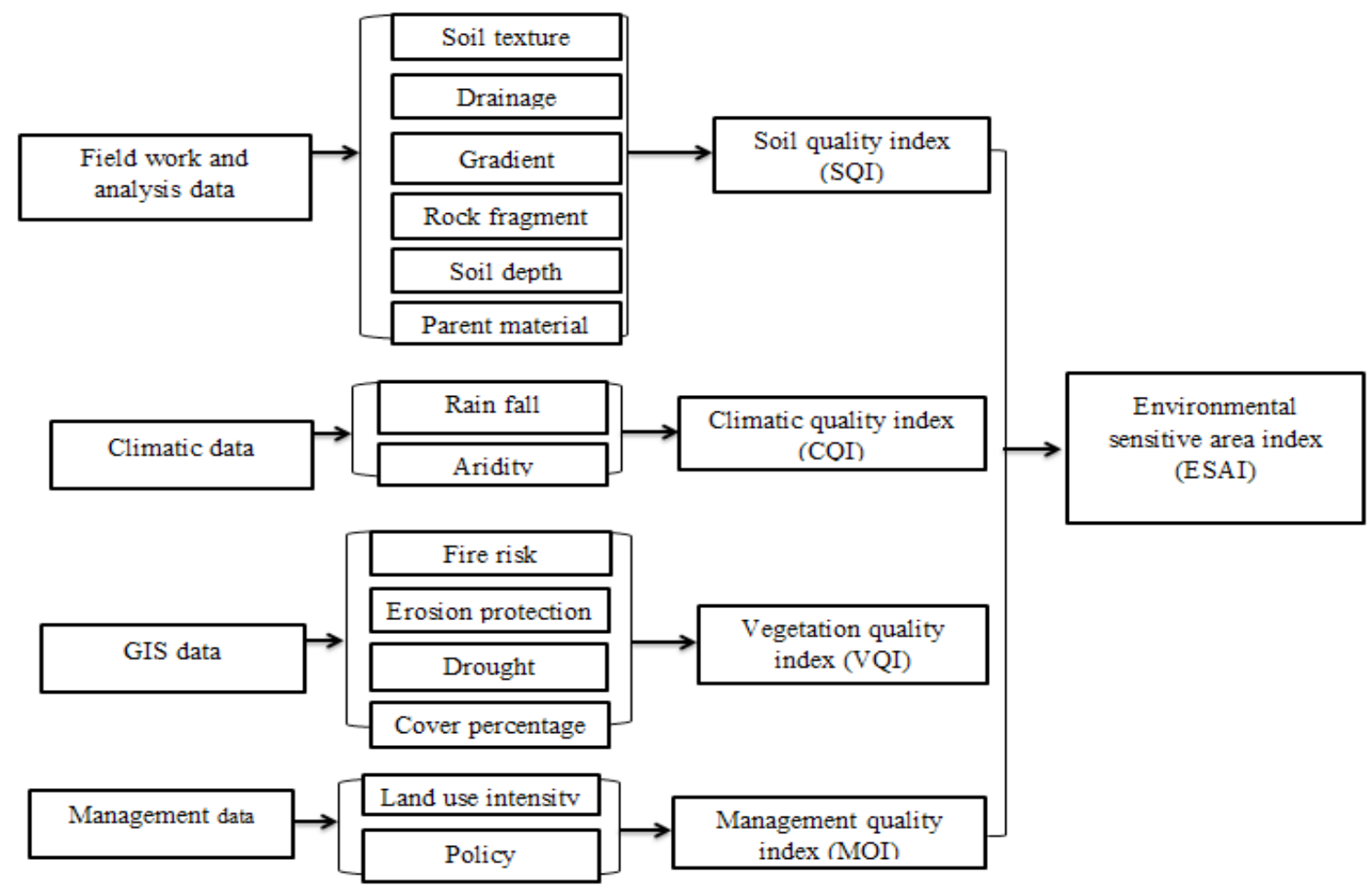

Fig. 3. Flow chart used incalculating theenvironmentally sensitive area (ESA) index

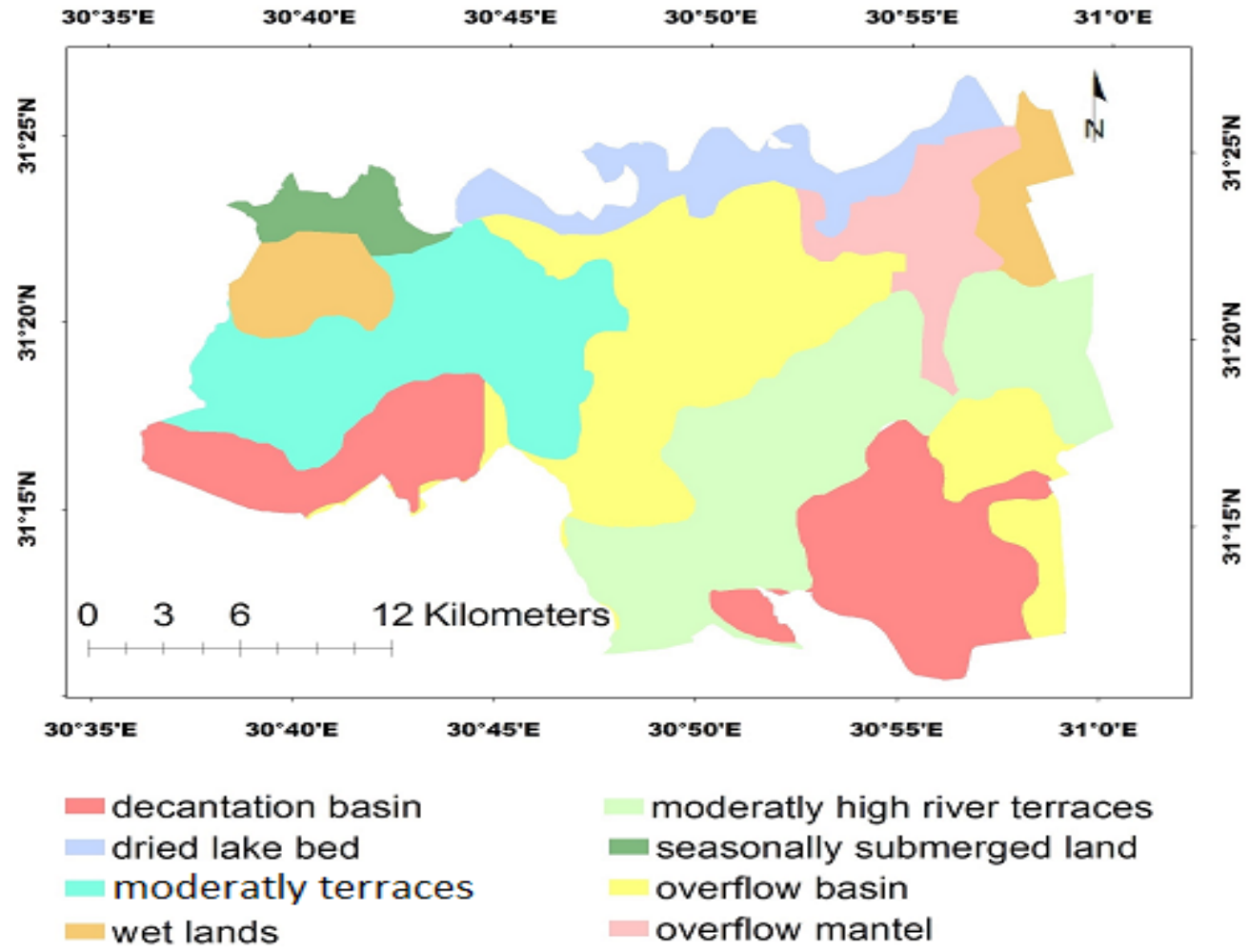

Fig. 4. Physiographic map unitswithinthe study area

Egypt. J. Soil Sci. 58, No.3 (2018) 


\section{Soil Quality Index (SQI)}

The soil quality index (SQI)used inmapping ESAs relies on the resistance of soil to erosion and soil water content. These qualities are ascertained inthe MEDALUS model through the use of soil properties or attributes customarily given in soil survey data. Examples include the relative amounts of sand, silt and clay particles, soil parent material, soil profile depth, surface slope angle, drainage type, and stoniness. The classes and allocated weighted indicesfor each of the six parametersare used to evaluate soil quality. Specifically, these parameters are the soil texture, which is classified based on its effects on desertification;the soil drainage condition, which is primarily utilized for assessing the risk of desertification;the soil depth, which is defined as the vertical distance within a soil profile from the soil surface to the watertable or hard layers; the surface slope gradient; the parent materials; and the rocky components.

The SQI is estimated from the weighted index assigned to each of the six parameters using Eq. (1): the total study area. Low soil quality dominates the areas characterized by shallow soil depths, high soil salinity and poor drainage. Moderate SQI values (1.13-.45) represent $37.33 \%$ of the total study area and are located in the northern part of the study area around LakeBurullus. These areas are characterized by shallow water table depths, moderately saline soils and poor drainage. The areas withhigh SQI values $(<1.13)$ represent $48.26 \%$ of the total study area, and the areas of high soil quality are located in the southern part of the study area.

\section{Climate quality indicators}

Climate quality is assessed in terms of parameters that impact the availability of water to plants, specifically rainfall, air temperatures and the aridity index. Many studies have been conducted to assess the relative roles that climate factors play in desertification and to reveal its underlying causes(Archer, 2004, Wang et al., 2005, Zheng et al., 2006). The CQIis calculated based on annual rainfall ( $\mathrm{mm}$ ) and the BagnoulsGaussenaridity index (BGI). The calculation of this index is straightforwardbecause the data

\section{$\mathrm{SQI}=\left(\text { texture* } \text { parent material* }^{*} \text { rock fragment* depth * slope * drainage }\right)^{1 / 6}$ Eq. (1)}

Soil quality fundamentally indicatesthe environmental sensitivity to desertification, particularly underarid and semi-arid conditions. Figure 5 and Table 1 represent the classes and areas of the SQIwithinthe study area. The areas with low SQI values $(>1.46)$ represent $14.42 \%$ of required can be easily obtained from common meteorological data. The CQI is calculated from the weighted index assigned to each of the factors from Eq. (2):

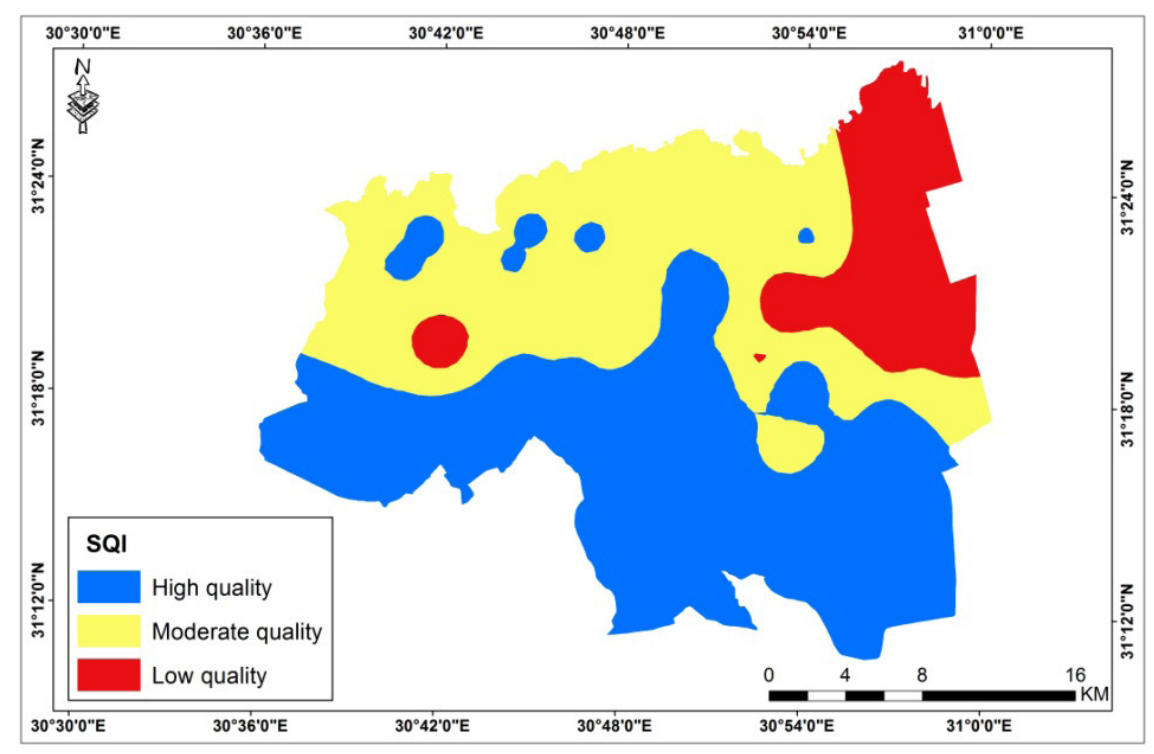

Fig. 5. Map showing soil quality index (SQI) values 
TABLE 1. Classification of the soil quality index (SQI)

\begin{tabular}{lccc}
\hline \multicolumn{1}{c}{ SQI class } & Area $\left(\mathbf{k m}^{2}\right)$ & Area (feddans) & \% \\
\hline High quality & 347.44 & 82724.12 & 48.26 \\
Moderate quality & 268.74 & 63986.86 & 37.33 \\
Low quality & 103.82 & 24719.19 & 14.42 \\
Total & 720.01 & 171430.17 & 100.00 \\
\hline
\end{tabular}

The CQI layer for this area indicates that it is characterized by low, moderate and high values $(>1.81,1.15-1.8$ and $<1.15)$ of the weighted index, respectively. These classes occupy $21.42,54.30$ and $24.28 \%$ of the total study area, respectively, as shown in Table 2 and Fig. 6.

Vegetation quality indicators

Vegetation quality is evaluated in terms of (1) fire risk and ability to recover; (2) the erosion protection that the vegetation affords to the soil; (3) drought resistance; and (4) the percentage of the soil area covered by plants. All of thefactors that affect the VQI depend on the type of vegetation cover. The fraction ofsoil cover is obtained from normalized difference vegetation index (NDVI) valuesderived from an $\mathrm{ETM}^{+}$satellite image (Fig.7). The VQI is assessed as the product of the vegetation attributes mentioned as being related to the sensitivity to desertification via Eq. (3):

$\mathrm{VQI}=($ fire risk $*$ erosion protection * drought resistance * vegetation cover) $1 / 4 \quad$ Eq. (3)

TABLE 2.Classification of the climate quality index (CQI)

\begin{tabular}{lccc}
\hline \multicolumn{1}{c}{ CQI class } & Area $\left(\mathbf{k m}^{2}\right)$ & Area (feddans) & \% \\
\hline High quality & 174.79 & 41615.77 & 24.28 \\
Moderate quality & 390.97 & 93087.80 & 54.30 \\
Low quality & 154.25 & 36726.60 & 21.42 \\
Total & 720.01 & 171430.17 & 100.00 \\
\hline
\end{tabular}

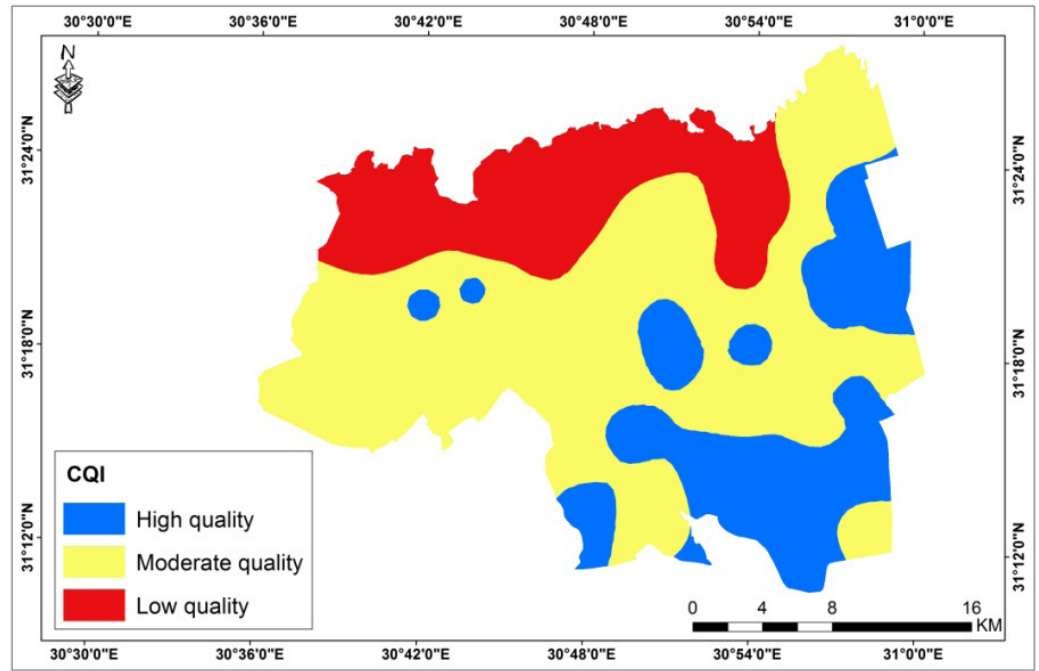

Fig. 6. Map showingclimate quality index (CQI) values 


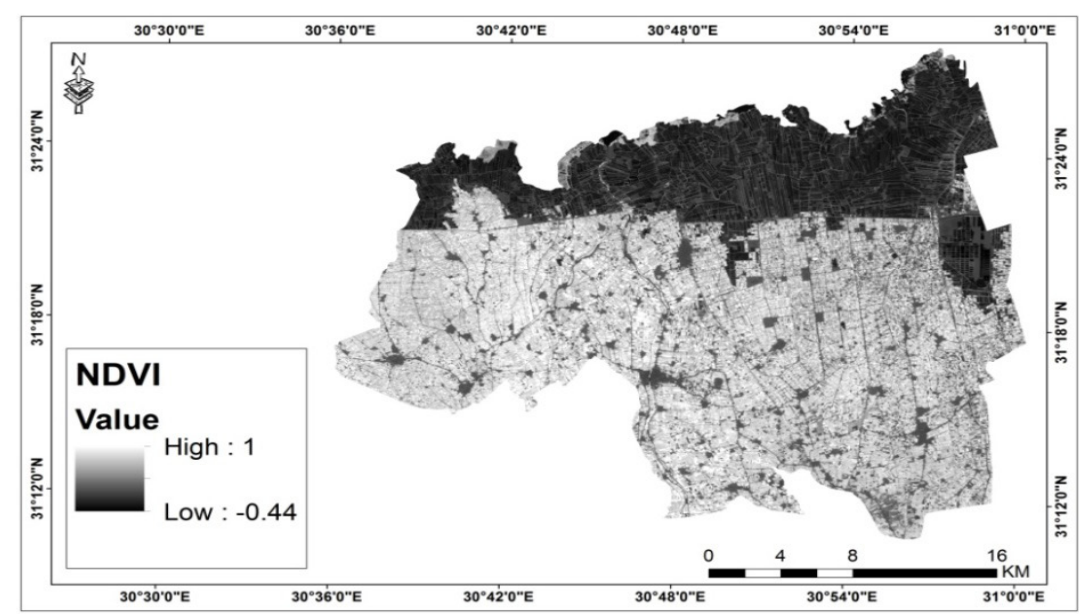

Fig. 7. Map showing normalized difference vegetation index (NDVI) values

The weightedVQI values are separated into the following orders: low, moderate and high ( $>1.6,1.3-1.6$ and $<1.3$, respectively). The weighted index assigned to each parameter is also considered in the calculation of the VQI. The VQI classes present within the study areacorrespond to $29.48,30.19$ and $40.34 \%$ of the studied soils, respectively, as shown in Table 3 and Fig.8.

\section{Management quality indicators}

The distribution of the MQIvaluesis shown in Table 4 and Figure 9 forthe studied soils. The MQI is assessed as a function of land utilization factorsand the implementation of policiesfor environmental protection viaEq. (4). At that point, the management quality is characterized utilizing model output. The MQI is calculated using the weighted index allocated to eachparameter as follows:

MQI = (land use intensity * policy enforcement $)^{1 / 2} \quad$ Eq. (4)

TABLE 3. Classification of the vegetation quality index (VQI)

\begin{tabular}{lccc}
\hline \multicolumn{1}{c}{ VQI class } & Area $\left(\mathbf{k m}^{2}\right)$ & Area (feddans) & \% \\
\hline High quality & 290.44 & 69152.48 & 40.34 \\
Moderate quality & 217.34 & 51746.46 & 30.19 \\
Low quality & 212.23 & 50531.23 & 29.48 \\
Total & 720.01 & 171430.17 & 100.00 \\
\hline
\end{tabular}

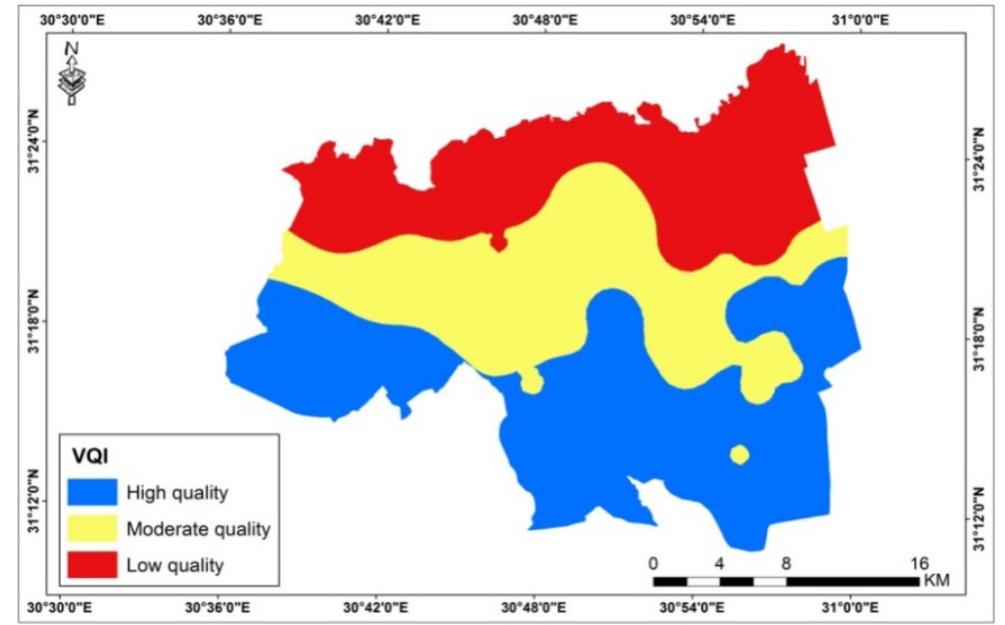

Fig. 8.Map showing vegetation quality index (VQI) values 
TABLE 4. Classification of the management quality index (MQI)

\begin{tabular}{lccc}
\hline \multicolumn{1}{c}{ MQI class } & Area $\left(\mathbf{k m}^{2}\right)$ & Area (feddans) & \% \\
\hline High quality & 236.51 & 56310.97 & 32.85 \\
Moderate quality & 274.32 & 65314.19 & 38.10 \\
Low quality & 209.18 & 49805.01 & 29.05 \\
Total & 720.01 & 171430.17 & 100.00 \\
\hline
\end{tabular}

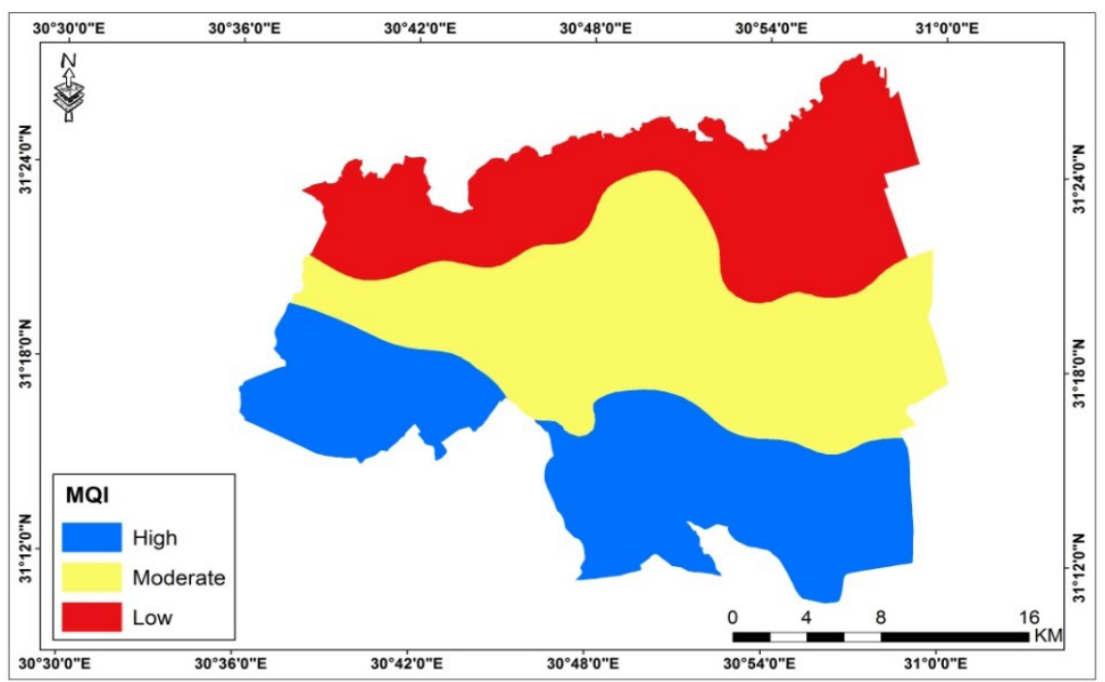

Fig.9. Map showing management quality index (MQI) values

Environmentally sensitive area (ESA) index

ESAs are areas of land and waterthat have sufficient ecological importance as to warrant their preservationin the best long-term consideration of the general population and environment.

The four previously mentionedindices are utilized together to identifythe areas that are sensitive to desertification. Fig. 10 and Table 5 demonstrate the extent of theseESAs.

The final ESA index that reflects sensitivity todesertification iscomputed as the geometric meanof the four quality indicesthat compose it:

$$
\mathrm{ESAI}=(\mathrm{SQI} * \mathrm{CQI} * \mathrm{VQI} * \mathrm{MQI}) \frac{1 / 4}{4} \quad \text { Eq. (5) }
$$

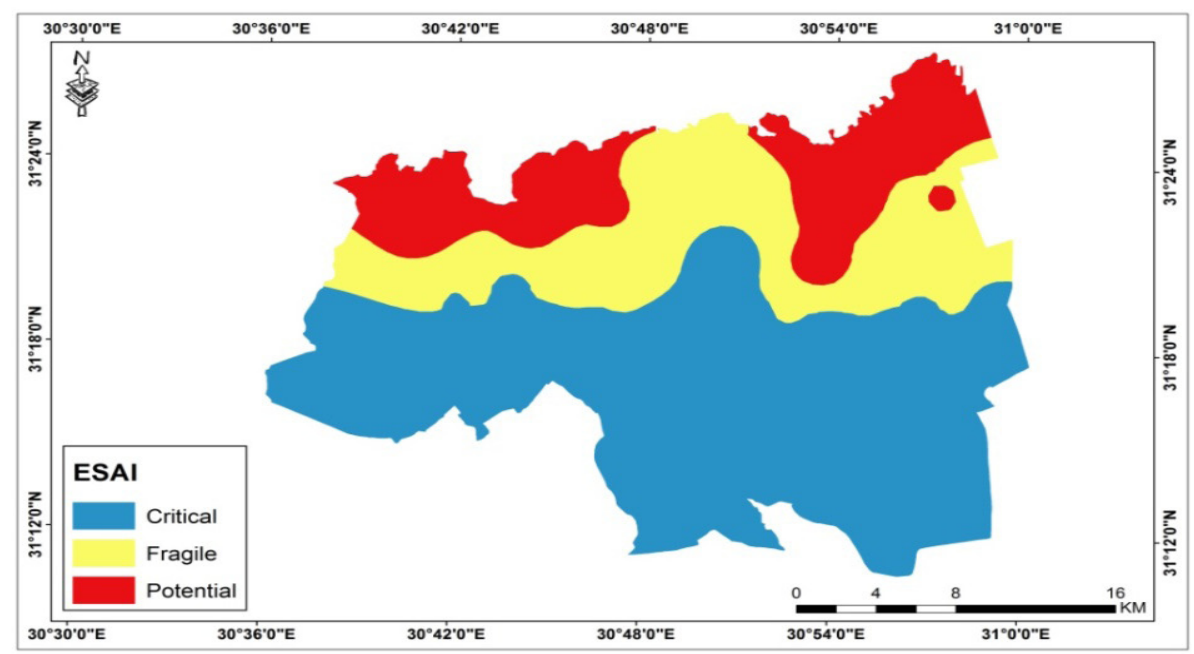

Fig. 10. Map showing classes of the environmentally sensitive area (ESA) index 
TABLE 10. Classification of the values of the environmentally sensitive area (ESA) index

\begin{tabular}{cccc}
\hline ESAindex class & Area $\left(\mathbf{k m}^{2}\right)$ & Area (feddans) & \% \\
\hline Critical & 408.54 & 97271.49 & 56.74 \\
Fragile & 175.10 & 41689.95 & 24.32 \\
Potential & 136.37 & 32468.73 & 18.94 \\
Total & 720.01 & 171430.17 & 100.00 \\
\hline
\end{tabular}

The results of environmentally sensitive area presented that the environmentally sensitive area index were classified to critical, fragile and potential index which represented 56.74, 24.32 and $19.94 \%$ respectively. The largest influence factors on sensitive area were soil salinity, waterlogging and management levels.The emphasis on sensitive to desertification is results of conflicts between human activities, increasing of population, limited land resources. Inadequate human activities, such as the overexploitation of natural resources and poor land management, contributed to some extent to environmental destruction.

\section{Conclusion}

The results obtained using the MEDALUS methodology highlight the extentand intensity of the threat to desertification in the northern Nile Delta ofEgypt. Geographicinformation system (GIS) processingis used to allow for the handling of significant amounts of data quickly and effectively and to integrate new sources of information derived from the processing of satellite images and from additional surveys or research. The results are used to obtain the final product of this work, which is a map of desertification vulnerability. This map provides an overview of the desertification phenomenon. This approach will help decision makers produceoptimal strategies for use in rehabilitation effortsand fight against desertification in sensitive areas.

\section{References}

Adger, W. N., Benjaminsen, T. A., Brown, K. and Svarstad, H. (2000) Advancing a Political Ecology of Global Environmental Discourses, University of East Anglia , London, Centre for Social and Economic Research on the Global Environment.

Adger, W. N., Benjaminsen, T. A., Brown, K. and Svarstad, H. (2001) Advancing a political ecology of global environmental discourses. Development and Change, 32, 681-715.
Archer, E. R. M. (2004) Beyond the "climate versus grazing" impasse: using remote sensing to investigate the effects of grazing system choice on vegetation cover in the eastern Karoo. Journal of Arid Environments, 57, 381-408.

Climatological Normal for Egypt (2011) The normal for Kafr El-Sheikh Governorate station (1960 2011), Ministry of Civil Aviation: Meteorological Authority, Cairo, Egypt.

Coscarelli, R., Caloiero, T., MinervinoI., and Sorriso, M. (2016) Sensitivity to desertification of a high productivity area in Southern Italy, Journal of Maps, 12, 573-581.

Dobos, E., Micheli, E., Baumgardner, M. F., Biehl, L. and Helt, T. (2000) Use of combined digital elevation model and satellite radiometric data for regional soil mapping. Geoderma, 97, 367-391.

FAO (1990) Guidelines for Soil Description, FAO, Rome.

Ferrara, A., Bellotti, A., Faretta, S., Mancino, G. and Taberner, M. (1999) Identification and assessment of environmentally sensitive areas by remote sensing. MEDALUS. King's College, London.

Gargi, C. (2015) Evaluating Environmental Sensitivity of Arid and Semiarid Regions in Northeastern Rajasthan, India. Geogr. Rev. 105, 441-461.

Gyssels, G.,, Poesen, J., Bochet, E and Li, Y. (2016) Impact of plant roots on the resistance of soils to erosion by water: A review. Prog. Phys. Geog. 29, 189-217.

Jabbar, M. T. and Chen, X. (2006) Land degradation assessment with the aid of geo-information techniques. Earth Surface Processes and Landforms, 31, 777-784.

Kosmas, C., Gerontidis, S. T., Detsis, V., Zafiriou, T. H. and Marathianou, M. (1999) Application of the MEDALUS methodology for defining ESAs in the Lesvos island. European Commision. 
Kosmas, C., Tsara, M., Moustakas, N. and Karavitis, C. (2003) Identification of indicators for desertification. Ann. Arid Zones, 42, 393-416.

Lahlaoi, H., Rhinane, H., Hilali, A., Lahssini, S., and Khalile, L. (2015) Potential Erosion Risk Calculation Using Remote Sensing and GIS in Oued El Maleh Watershed, Morocco. J. Geogr. Inf. Syst. 7, 128-139.

Lahlaoi, H., Rhinane, H., Hilali, A., Lahssini, S. and Moukrim, S. (2017) Desertification Assessment Using MEDALUS Model in Watershed Oued El Maleh, Morocco. Geosciences. 7, 50.

Lavado, C. J. F., S., S., Gómez, G. A. and Pulido, F. M. (2009) Mapping sensitivity to land degradation in Extremadura. SW Spain. Land Degradation \& Development, 20, 129-144.

Lillesand, T. M. and Kiefer, R. W. (2007) Remote Sensing and Image Interpretation, John Wiley, New York.

Nicholson, S. E., Tucker, C. J. and Ba, M. B. (1998) Desertification, Drought, and Surface Vegetation: An Example from the West African Sahel. Bulletin of the American Meteorological Society, 79, 815830 .

Runnström, M. C. (2003) Rangeland development of the Mu Us Sandy Land in semiarid China: an analysis using Landsat and NOAA remote sensing data. Land Degradation \& Development, 14, 189202.

Saleh, A. M., Belal, A. B. and Jalhoum, M. E. (2018) Quantitative Assessment of Environmental Sensitivity to Desertification in Sidi Abdel-Rahman Area, Northern West Coast of Egypt. Egypt. J. Soil Sci. 58, (1), 13 -26.

Sepehr, A., Hassanli, A. M., Ekhtesasi, M. R. \& Jamali, J. B. (2007) Quantitative assessment of desertification in south of Iran using MEDALUS method. Environmental Monitoring and Assessment, 134, 243.
Thomas, D. S. G. (1997) Science and the desertification debate. Journal of Arid Environments, 37, 599-608.

USDA (2004) Soil Survey Laboratory Methods Manual. Soil Survey Investigation Report No. 42 Version 4.0, USDA-NRCS, Lincoln, Nebraska.

Wang, X., Chen, F. H., Dong, Z. and Xia, D. (2005) Evolution of the southern Mu US desert in north China over the past 50 years: an analysis using proxies of human activity and climate parameters. Land Degradation \& Development, 16, 351-366.

Westervelt, J. D. (2002) Geographic information systems and agent-based modelling. In: R., G. H. (Ed.) Integrating Geographic Information Systems and Agent $\square$ Based Modeling Techniques for Simulating Social and Ecological Processes. Oxford University Press, Oxford.

World Meteorological Organization (2005) The Abridged Final Report with Resolutions and ecommendations of the Fourteenth Session of the Commission for Climatology, Beijing, China, 3-10 November 2005, WMO-No, 996.

Yang, X., Ding, Z., Fan, X., Zhou, Z. and Ma, N. (2007) Processes and mechanisms of desertification in Northern China during the last 30 years, with a special reference to the Hunshandake Sandy Land, Eastern Inner Mongolia. CATENA, 71, 2-12.

Zambon, I., Colantoni A., Carlucci M., Morrow N., Sateriano, A. and Salvati L. (2017) Land quality, sustainable development and environmental degradationin agricultural districts: A computational approach based onentropy indexes. Environmental Impact Assessment Review, 64, 37-46.

Zheng, Y. R., Xie, Z. X., Robert, C., Jiang, L. H. and Shimizu, H. (2006) Did climate drive ecosystem change and induce desertification in Otindag sandy land, China over the past 40 years? Journal of Arid Environments, 64, 523-541.

(Received: 18/6/2018; accepted:12/9/2018) 


\section{تقبيمة ورسم خرائط المناطق الحساسة بيئيا للتصحر باستخدام تقنيات الإستثعار من بعد في

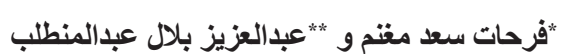

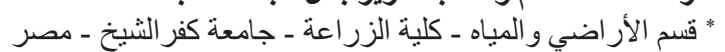

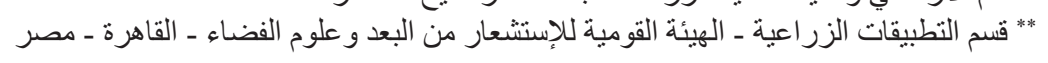

تهدف هذه الدر اسلة الى تقييم المناطق الحساسة بيئيا للتصحر ورسم خر ائط لها باستخدام التكامل بين الاستشعار عن بعد ونظم المعلومات الجغر افية (GIS) في الجزء الثمالي من دلتا النيل، مصر.

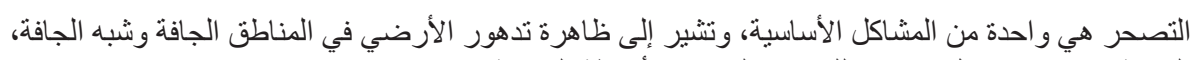
الناتجة عن عدة عوامل بما في ذلك تغير المناخ والأنشطة البشرية.

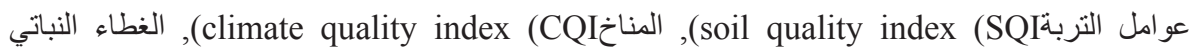
(vegetation quality index (VQI

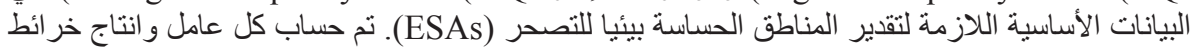

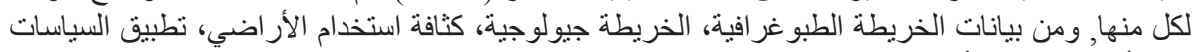

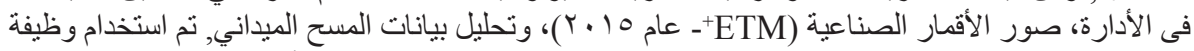

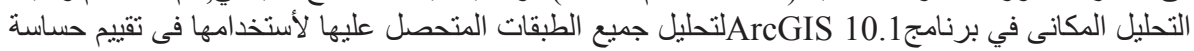
منطقة الدر اسة بيئيا للتصحر.

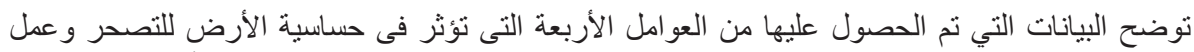

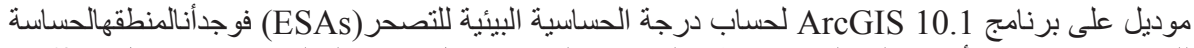

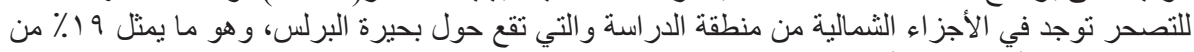

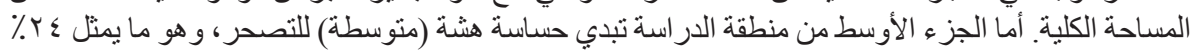

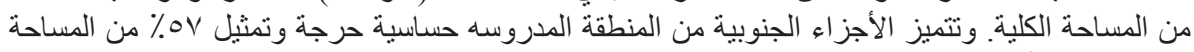

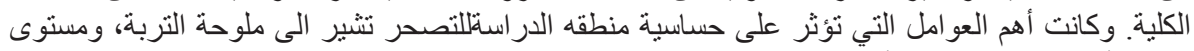

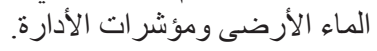

